AGRO-INDUSTRI

Vol. 3 No.1 ; Juni 2016

\title{
PENENTUAN FORMULASI DAN UMUR SIMPAN SOSIS BUAH DENGAN PENAMBAHAN TEPUNG TAPIOKA
}

\author{
${ }^{*}$ NINA HAIRIYAH ${ }^{1}$, JUBAIDAH $^{1}$ \\ ${ }^{1}$ Jurusan Teknologi Industri Pertanian, Politeknik Negeri Tanah Laut, Jl. A. Yani, Km. 6, Ds. \\ Panggung, kec. Pelaihari, kab Tanah Laut, Kalimantan Selatan
}

Naskah diterima 21 April 2016 : ; Naskah disetujui : 24 Mei 2016

\begin{abstract}
ABSTRAK
Sosis merupakan produk olahan daging yang dihaluskan dan dicampur dengan rempahrempah. Sosis tidak dapat di konsumsi oleh seluruh lapisan masyarakat, karena ada sebagian orang yang tidak memakan daging (vegetarian), alergi ataupun tidak mampu membeli. Salah satu hal yang dapat dilakukan agar seluruh masyarakat dapat mengkonsumsi sosis adalah dengan mengganti bahan baku daging menjadi buah. Di Kabupaten Tanah Laut buah-buahan yang pemanfaatannya belum optimal antara lain adalah buah pisang, buah naga dan buah pepaya, sehingga pada penelitian ini akan dioleah sosis berbahan baku buah pisang, buah naga dan buah pepaya. Tujuan dari penelitian ini adalah untuk mendapatkan formulasi terbaik dari pembuatan produk sosis buah. Analisis yang dilakukan pada produk sosis buah yaitu uji organoleptik dan uji umur simpan dengan metode ESS. Hasil pengolahan data menunjukkan bahwa sosis buah dengan formulasi terbaik adalah produk sosis buah pisang, buah naga dan buah pepaya pada perlakuan $C$ $(T 50 \%=50 \mathrm{~g}$ tapioka $: 50 \mathrm{~g}$ buah) dengan perolehan nilai kesukaan rata-rata tertinggi. Produk sosis buah dapat bertahan selama 15 hari dengan penyimpanan di dalam freezer.
\end{abstract}

Kata kunci: Sosis, sosis buah, buah pisang, buah naga, buah pepaya, uji organoleptic, uji umur simpan

\section{PENDAHULUAN}

Menurut Rahardjo (2003) di dalam Witanto dkk (2013) sosis merupakan makanan olahan dari daging khususnya daging sapi dan ayam atau campuran beberapa daging yang dihaluskan serta dicampur dengan bumbu-bumbu atau rempah-rempah. Pada umumnya sosis dibuat dari daging ayam, ikan, sapi dan kelinci. Sebagai salah satu penganan, variasi olahan sosis mempunyai prospek yang cerah dan digemari masyarakat. Hal yang perlu diperhatikan dalam olahan sosis yaitu bahan pengikat. Produk sosis dengan kualitas yang baik memerlukan tepung sebagai bahan pengikat (Prastini, 2015).

Pada saat ini olahan makanan berupa sosis sangat banyak, akan tetapi bahan baku yang digunakan hanya dari daging) saja, namun terdapat sebagian masyarakat yang tidak dapat mengkonsumsi berbagai macam daging hewani karena vegetarian, kurang mampu untuk membeli atau alergi terhadap daging. Berdasarkan hal tersebut, salah satu solusinya adalah dengan cara mengganti bahan baku sosis yang awalnya hanya diolah dari daging hewani diganti dengan berbagai macam buah misalnya seperti buah pepaya, pisang dan buah naga yang tentunya sangat mudah dijumpai di seluruh wilayah Indonesia terutama di Kalimantan Selatan khususnya di Kabupaten Tanah Laut.

\footnotetext{
*Korespondensi:

Telp. : 085248751988

Email : ninahairiyah@gmail.com
} 
Beberapa penelitian terkait pembuatan sosis yang tidak berbasis daging diantaranya adalah penelitian yang dilakukan oleh Witanto dkk (2013) tentang pembuatan sosis berbasis jamur tiram putih dengan tepung rebung untuk mengahsilkan produk sosis nabati yang menyehatkan. Penelitian tersebut menyimpulkan bahwa produk sosis jamur tiram putih dan tepung rebung dengan kombinasi tapioca dan karagenan berpengaruh terhadap sifat fisik tekstur sosis, sifat kimia (kadar air, abu, serat, lemak dan protein).

Penelitian lain yaitu yang dilakukan oleh Khotimah dkk (2013) tentang pembuatan sosis daging ayam dengan penambahan labu merah untuk mengetahui pengaruh penggunaan labu merah sebagai pengganti warna dan antioksidan yang didasarkan pada kualitas fisiko kimia sosis ayam. Penelitian ini menyimpulkan bahwa penggunaan labu merah pada sosis ayam memberikan kualitas fisik (tekstur) dan kimiawi (kadar air, kadar protein, dan kadar lemak) yang baik dan bisa diterima oleh konsumen melalui uji organoleptik.

Tujuan dari penelitian ini adalah 1) mendapatkan formulasi terbaik dari sosis buah pisang, sosis buah naga sosis buah pepaya dan 2) mengetahui lama umur simpan pada produk sosis buah.

\section{METODE PENELITIAN}

Rancangan penelitian yang dilakukan yaitu, membuat produk sosis buah pisang, buah naga dan buah pepaya dengan memvariasikan penambahan tepung tapioka. Terdapat tiga perlakukan pada tiap masing-masing jenis buah dimana persen penambahan tepung tapioka terhadap buah berbeda-beda, yaitu T20 \%= $20 \mathrm{~g}$ tapioka : $80 \mathrm{~g}$ buah, T35\% = $35 \mathrm{~g}$ tapioka : $65 \mathrm{~g}$ buah dan T50\% $=50 \mathrm{~g}$ tapioka $: 50 \mathrm{~g}$ buah.

\section{Pembuatan Sosis Buah Pisang}

Disiapkan alat dan bahan kemudian dikupas kulit buah pisang dan diambil dagingnya. Dilakukan penimbangan buah pisang dengan perbandingan antara buah dan tepung yaitu T $20 \%$ (20 g Tapioka : $80 \mathrm{~g}$ Buah), $\mathrm{T}$ 35\% (35 g Tapioka : $65 \mathrm{~g}$ Buah) dan T 50\% (50 g Tapioka : $50 \mathrm{~g}$ Buah). Ditimbang pula bahan pelengkap seperti gula pasir $30 \mathrm{~g}$, garam $5 \mathrm{~g}$, susu $20 \mathrm{~g}$ dan santan 50 ml. selanjutnya dilakukan pencampuran terhadap seluruh bahan dengan menggunakan mixer hingga halus. Setelah halus, dimasukkan adonan ke dalam casing atau selongsong sosis dengan lebar $3 \mathrm{~cm}$. kemudian direbus sosis ke dalam air mendidih dengan suhu $100^{\circ} \mathrm{C}$ selama 30 menit. Setelah sosis mulai terlihat mengapung dipermukaan air langkah selanjutnya adalah sosis diangkat kemudian ditiriskan lalu direndam sosis ke dalam air es. Kemudian sosis buah pisang disimpan ke dalam freezer. Pada pembuatan produk sosis buah naga dan buah pepaya sama halnya dengan perlakuan pada sosis buah pisang.

\section{Uji Organoleptik}

Disiapkan 9 sampel produk sosis buah +1 sampel produk sosis tanpa buah sebagai control. Selanjutnya disiapkan ruangan untuk proses pengujian dan dilakukan uji organoleptik terhadap produk sosis buah yang dilakukan oleh 15 orang panelis terlatih secara bergiliran dengan parameter yang diuji yaitu rasa, aroma, warna dan tektur.

\section{Pengujian Umur Simpan}

Uji umur simpan pada produk sosis buah pisang, buah naga dan buah pepaya dilakukan dengan cara mengamati produk selama 30 hari dengan cara menyimpan produk di dalam freezer 
dengan suhu $1^{\circ} \mathrm{C}$. Parameter yang digunakan pada pengamatan tersebut yaitu rasa, aroma, warna dan tekstur.

\section{Pembuatan Media}

Disiapkan semua alat yaitu hot plate, autoclave, tabung reaksi, magnetic stirrer, aluminum foil dan karet gelang, sedangkan bahan yang digunakan adalah (Medium NA (Nutrient Agar) 5,6 g dan aquades $200 \mathrm{ml}$ ), dimasukkan medium NA ke dalam erlenmeyer dan ditambahkan aquades $200 \mathrm{ml}$ kemudian diaduk dan dipanaskan dengan hot plate menggunkan magnetik stirrer dengan suhu $250^{\circ} \mathrm{C}$. Kemudian disiapkan 9 buah tabung reaksi masing-masing tabung reaksi diisi dengan aquades sebanyak $9 \mathrm{ml}$, kemudian ditutup dengan aluminum foil hingga rapat. Tabung reaksi dan labu erlenmeyer yang telah diisi, dimasukkan ke dalam autoclave untuk disterilkan pada suhu $121^{\circ} \mathrm{C}$ selama 15 menit. NA (Nutrient agar) yang diperlukan untuk pembuatan medium dilarutkan dalam $200 \mathrm{ml}$ aquades yaitu:

$$
\begin{aligned}
\text { Banyaknya } \mathrm{NA} & =\frac{1000 \mathrm{mI}}{28 \mathrm{~g}}=\frac{200 \mathrm{~mL}}{\mathrm{x}} \\
\mathrm{x} & =\frac{200 \mathrm{~mL} \cdot 28 \mathrm{~g}}{1000 \mathrm{~mL}} \\
\mathrm{x} & =5,6 \mathrm{~g}
\end{aligned}
$$

\section{Isolasi Mikroba}

Disiapkan alat yaitu neraca analitik, tabung reaksi, kertas label, lampu bunsen, rak tabung reaksi, dan mikro pipet sedangkan bahan yang digunakan yaitu media NA dan alkohol. Dibersihkan laminar kemudian disemprot dengan alkohol untuk disterilkan. Ditimbang masing - masing sampel sosis buah sebanyak $1 \mathrm{~g}$, selanjutnya hidupkan lampu bunsen kemudian masukkan masing-masing sampel ke dalam tabung reaksi. Kemudian sampel di dalam tabung reaksi diambil sebanyak $1 \mathrm{ml}$ menggunakan mikro pipet dan dimasukkan ke dalam cawan yang telah disterilkan disebelah lampu bunsen, kemudian masukkan media NA ke dalam cawan yang telah berisi sampel. Selanjutnya cawan petri digerakkan diatas meja seperti angka 8 agar sampel dan media merata. Diinkubasi selama 24 jam.

\section{Identifikasi Mikroba}

Tahap persiapan (pembuatan preparat ulas)

Kaca objek dibersihkan dengan kapas dan alkohol. Diteteskan 2 mata ose aquades steril di tengah kaca objek. Ose disentuhkan pada biakan bakteri. Biakan dicampurkan dengan aquades pada kaca objek yang telah disiapkan sebelumnya. Difiksasi di atas api.

\section{Pewarnaan Gram}

Preparat ulas yang sudah dibuat ditambahkan kristal violet beberapa tetes, kemuudian didiamkan selama 1 menit kemudian dicuci dengan air mengalir. Tambahkan larutan lugol beberapa tetes, kemudian didiamkan 1 menit, dan dicuci dengan air. Diteteskan larutan pemucat (alkohol) selama 10-20 detik, kemudian dicuci dengan air. Ditetesi larutan safranin, kemudian didiamkan 1 menit dan dicuci dengan air, kemudian dikeringkan dengan tisu dan diamati dengan mikroskop. 


\section{HASIL DAN PEMBAHASAN}

\section{Uji Organoleptik}

Berdasarkan uji organoleptik yang dilakukan pada produk sosis buah pisang, buah naga dan buah pepaya parameter yang digunakan dengan parameter rasa, aroma, warna dan tekstur, maka didapatkan hasil skor rata-rata penilaian seperti yang disajikan pada Gambar 1.
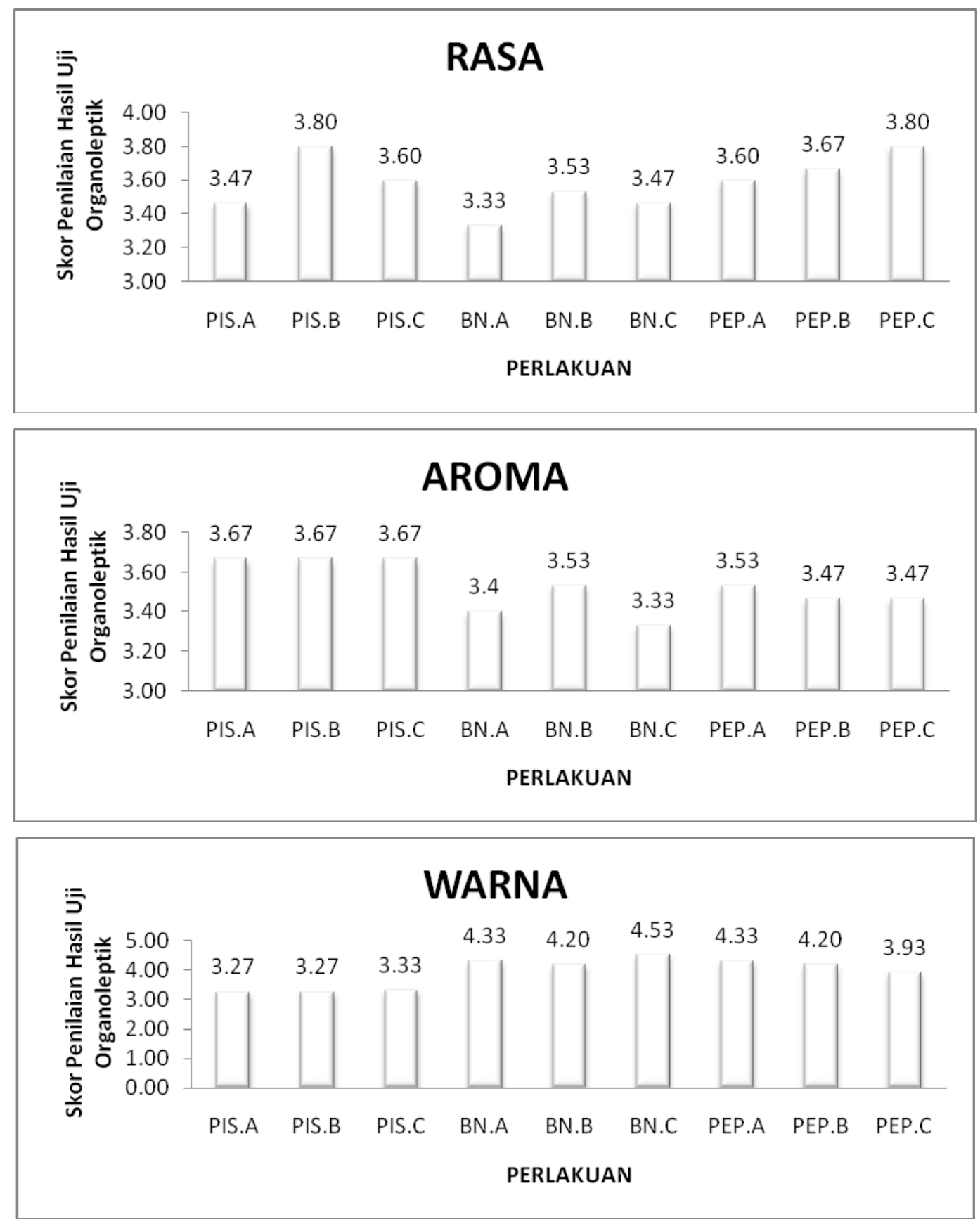

Gambar 1. Hasil penilaian uji organoleptik

Uji organoleptik yang dilakukan adalah uji hedonik yang bertujuan untuk mengetahui tingkat kesukaan terhadap produk aneka sosis dengan penambahan tepung tapioca yang berbeda- 
beda. Pada sosis buah pisang dan buah naga B dengan perbandingan tepung sebanyak 35\% yang berarti memiliki rasa pisang dan buah naga yang agak kuat. Sedangkan pada sosis buah papaya rasa yang paling banyak disukai oleh Panelis yaitu sosis buah papaya $\mathrm{C}$ dengan perbandingan tepung tapioca sebanyak 50\%. Hal ini dikarenakan buah papaya memiliki rasa yang agak keasaman sehingga sosis buah papaya dengan perlakuan $\mathrm{C}$ merupakan formulasi yang tepat untuk digunakan. Rasa lebih banyak melibatkan panca indera lidah. Bahan makanan yang mempunyai sifat merangsang syaraf perasa akan menimbulkan perasaan tertentu. Cita rasa makanan merupakan salah satu faktorpenentu bahan makanan. Makanan yang memiliki rasa yang enak dan menarik akan disukai oleh konsumen (Winarno, 2004).

Penilaian aroma pada sosis buah pisang menunjukkan angka yang sama yaitu 3,67. Hal ini menunjukkan bahwa penambahan sedikit atau banyaknya tepung tapioka ke dalam buah pisang tidak mempengaruhi terhadap aroma yang akan dihasilkan karena aroma buah pisang sangat kuat dibandingkan dengan buah naga dan buah papaya. Pada sosis buah naga aroma yang paling banyak disukai oleh Panelis yaitu sosis buah naga B dengan perbandingan tepung terigu 35\%, hal ini disebabkan sosis buah perlakuan B aroma buah naga tidak terlalu kuat sehingga tidak beraroma langu. Pada sosis buah pepaya aroma yang paling banyak disukai oleh Panelis yaitu pada sosis buah pepaya A dengan perbandingan tepung sebanyak 20\%, hal ini disebabkan karena semakin sedikit penambahan tepung tapioka terhadap buah pepaya maka aroma buah pepaya akan lebih terasa. Aroma adalah salah satu faktor yang menentukan mutu dari bahan pangan, pada umumnya bau yang diterima oleh hidung dan otak lebih banyak merupakan berbagai ramuan atau campuran empat bau utama yaitu harum, asam, tengik dan hangus (Anwar, 2012).

Pada sosis buah pisang dan buah naga warna yang paling banyak disukai oleh Panelis yaotu sosis buah pisang dan buah naga $\mathrm{C}$ dengan perbandingan tepung 50\%. Pada sosis buah pepaya warna yang paling banyak disukai oleh konsumen yaitu sosis pepaya A dengan perbandingan tepung sebanyak $20 \%$ yang berarti memiliki warna orange cerah, hal ini disebabkan karena warna pada produk sosis buah pepaya A lebih menarik dibandingkan dengan sosis pepaya B dan C. Warna meruapakan salah satu faktor yang menentukan mutu secara visual warna tampil lebih dahulu dan kadang-kadang sangat menentukan, sehingga warna diajdikan atribut yang oenting adalah suatu bahan pangan (Winarno, 2002).

Pada sosis buah pisang, buah naga dan pepaya tekstur yang paling banyak disukai yaitu pada sosis buah $\mathrm{C}$ dengan perbandingan tepung sebanyak 50\%, hal ini disebabkan karena semakin meningkat penambahan tepung tapioka terhadap adonan maka semakin bagus tekstur yang dihasilkan. Menurt Anwar dan Putri (2010) tekstur adalah penginderaan yang berhubunngan dengan rabaan dan sentuhan.

\section{Uji Umur Simpan Produk}

Pada uji ketahanan mutu atau uji umur simpan produk sosis buah pisang, buah naga dan buah pepaya yang disimpan pada freezer dengan suhu $1^{\circ} \mathrm{C}$ didapatkan hasil yaitu produk sosis buah pisang, buah naga dan buah pepaya mampu bertahan selama 15 hari. Adapun hasil uji umur simpan dengan menggunakan uji organoleptik pada produk sosis buah dapat dilihat pada Tabel 1 . 
Tabel 1. Umur Simpan Pada Sosis Buah Pisang

\begin{tabular}{|c|c|c|c|c|c|c|c|c|c|c|c|c|c|c|c|c|c|c|}
\hline \multirow{2}{*}{ Parameter } & \multirow{2}{*}{ Perlakuan } & \multicolumn{17}{|c|}{ Hari } \\
\hline & & $\mathbf{0}$ & 1 & 2 & 3 & 4 & 5 & 6 & 7 & 8 & 9 & 10 & 11 & 12 & 13 & 14 & 15 & 16 \\
\hline \multirow{3}{*}{ Rasa } & $20 \%$ & 5 & 5 & 5 & 5 & 5 & 5 & 5 & 5 & 5 & 5 & 5 & 5 & 5 & 5 & 5 & 5 & 3 \\
\hline & $35 \%$ & 5 & 5 & 5 & 5 & 5 & 5 & 5 & 5 & 5 & 5 & 5 & 5 & 5 & 5 & 5 & 5 & 3 \\
\hline & $50 \%$ & 4 & 4 & 4 & 4 & 4 & 4 & 4 & 4 & 4 & 4 & 4 & 4 & 4 & 4 & 4 & 4 & 3 \\
\hline \multirow{3}{*}{ Aroma } & $20 \%$ & 5 & 5 & 5 & 5 & 5 & 5 & 5 & 5 & 5 & 5 & 5 & 5 & 5 & 5 & 5 & 5 & 3 \\
\hline & $35 \%$ & 5 & 5 & 5 & 5 & 5 & 5 & 5 & 5 & 5 & 5 & 5 & 5 & 5 & 5 & 5 & 5 & 3 \\
\hline & $50 \%$ & 4 & 4 & 4 & 4 & 4 & 4 & 4 & 4 & 4 & 4 & 4 & 4 & 4 & 4 & 4 & 4 & 2 \\
\hline \multirow{3}{*}{ Warna } & $20 \%$ & 5 & 5 & 5 & 5 & 5 & 5 & 5 & 5 & 5 & 5 & 5 & 5 & 5 & 5 & 5 & 5 & 4 \\
\hline & $35 \%$ & 5 & 5 & 5 & 5 & 5 & 5 & 5 & 5 & 5 & 5 & 5 & 5 & 5 & 5 & 5 & 5 & 3 \\
\hline & $50 \%$ & 4 & 4 & 4 & 4 & 4 & 4 & 4 & 4 & 4 & 4 & 4 & 4 & 4 & 4 & 4 & 4 & 3 \\
\hline \multirow{3}{*}{ Tekstur } & $20 \%$ & 4 & 4 & 4 & 4 & 4 & 4 & 4 & 4 & 4 & 4 & 4 & 4 & 4 & 4 & 4 & 4 & 3 \\
\hline & $35 \%$ & 5 & 5 & 5 & 5 & 5 & 5 & 5 & 5 & 5 & 5 & 5 & 5 & 5 & 5 & 5 & 5 & 3 \\
\hline & $50 \%$ & 3 & 3 & 3 & 3 & 3 & 3 & 3 & 3 & 3 & 3 & 3 & 3 & 3 & 3 & 3 & 3 & 2 \\
\hline
\end{tabular}

Tabel 2. Umur Simpan Pada Sosis Buah Naga

\begin{tabular}{|c|c|c|c|c|c|c|c|c|c|c|c|c|c|c|c|c|c|c|}
\hline \multirow{2}{*}{ Parameter } & \multirow{2}{*}{ Perlakuan } & \multicolumn{17}{|c|}{ Hari } \\
\hline & & $\mathbf{0}$ & 1 & 2 & 3 & 4 & 5 & 6 & 7 & 8 & 9 & 10 & 11 & 12 & 13 & 14 & 15 & 16 \\
\hline \multirow{3}{*}{ Rasa } & $20 \%$ & 5 & 5 & 5 & 5 & 5 & 5 & 5 & 5 & 5 & 5 & 5 & 5 & 5 & 5 & 5 & 5 & 3 \\
\hline & $35 \%$ & 5 & 5 & 5 & 5 & 5 & 5 & 5 & 5 & 5 & 5 & 5 & 5 & 5 & 5 & 5 & 5 & 3 \\
\hline & $50 \%$ & 5 & 5 & 5 & 5 & 5 & 5 & 5 & 5 & 5 & 5 & 5 & 5 & 5 & 5 & 5 & 5 & 3 \\
\hline \multirow{3}{*}{ Aroma } & $20 \%$ & 3 & 3 & 3 & 3 & 3 & 3 & 3 & 3 & 3 & 3 & 3 & 3 & 3 & 3 & 3 & 3 & 2 \\
\hline & $35 \%$ & 3 & 3 & 3 & 3 & 3 & 3 & 3 & 3 & 3 & 3 & 3 & 3 & 3 & 3 & 3 & 3 & 2 \\
\hline & $50 \%$ & 3 & 3 & 3 & 3 & 3 & 3 & 3 & 3 & 3 & 3 & 3 & 3 & 3 & 3 & 3 & 3 & 2 \\
\hline \multirow{3}{*}{ Warna } & $20 \%$ & 5 & 5 & 5 & 5 & 5 & 5 & 5 & 5 & 5 & 5 & 5 & 5 & 5 & 5 & 5 & 5 & 4 \\
\hline & $35 \%$ & 5 & 5 & 5 & 5 & 5 & 5 & 5 & 5 & 5 & 5 & 5 & 5 & 5 & 5 & 5 & 5 & 3 \\
\hline & $50 \%$ & 5 & 5 & 5 & 5 & 5 & 5 & 5 & 5 & 5 & 5 & 5 & 5 & 5 & 5 & 5 & 5 & 3 \\
\hline \multirow{3}{*}{ Tekstur } & $20 \%$ & 4 & 4 & 4 & 4 & 4 & 4 & 4 & 4 & 4 & 4 & 4 & 4 & 4 & 4 & 4 & 4 & 3 \\
\hline & $35 \%$ & 3 & 3 & 3 & 3 & 3 & 3 & 3 & 3 & 3 & 3 & 3 & 3 & 3 & 3 & 3 & 3 & 2 \\
\hline & $50 \%$ & 3 & 3 & 3 & 3 & 3 & 3 & 3 & 3 & 3 & 3 & 3 & 3 & 3 & 3 & 3 & 3 & 2 \\
\hline
\end{tabular}

Tabel 3. Umur Simpan Pada Sosis Buah Pepaya

\begin{tabular}{|c|c|c|c|c|c|c|c|c|c|c|c|c|c|c|c|c|c|c|}
\hline \multirow{2}{*}{ Parameter } & \multirow{2}{*}{ Perlakuan } & \multicolumn{17}{|c|}{ Hari } \\
\hline & & $\mathbf{0}$ & 1 & 2 & 3 & 4 & 5 & 6 & 7 & 8 & 9 & 10 & 11 & 12 & 13 & 14 & 15 & 16 \\
\hline \multirow{3}{*}{ Rasa } & $20 \%$ & 5 & 5 & 5 & 5 & 5 & 5 & 5 & 5 & 5 & 5 & 5 & 5 & 5 & 5 & 5 & 5 & 3 \\
\hline & $35 \%$ & 5 & 5 & 5 & 5 & 5 & 5 & 5 & 5 & 5 & 5 & 5 & 5 & 5 & 5 & 5 & 5 & 3 \\
\hline & $50 \%$ & 4 & 4 & 4 & 4 & 4 & 4 & 4 & 4 & 4 & 4 & 4 & 4 & 4 & 4 & 4 & 4 & 3 \\
\hline \multirow{3}{*}{ Aroma } & $20 \%$ & 4 & 4 & 4 & 4 & 4 & 4 & 4 & 4 & 4 & 4 & 4 & 4 & 4 & 4 & 4 & 4 & 3 \\
\hline & $35 \%$ & 4 & 4 & 4 & 4 & 4 & 4 & 4 & 4 & 4 & 4 & 4 & 4 & 4 & 4 & 4 & 4 & 3 \\
\hline & $50 \%$ & 3 & 3 & 3 & 3 & 3 & 3 & 3 & 3 & 3 & 3 & 3 & 3 & 3 & 3 & 3 & 3 & 2 \\
\hline \multirow{3}{*}{ Warna } & $20 \%$ & 4 & 4 & 4 & 4 & 4 & 4 & 4 & 4 & 4 & 4 & 4 & 4 & 4 & 4 & 4 & 4 & 3 \\
\hline & $35 \%$ & 4 & 4 & 4 & 4 & 4 & 4 & 4 & 4 & 4 & 4 & 4 & 4 & 4 & 4 & 4 & 4 & 3 \\
\hline & $50 \%$ & 3 & 3 & 3 & 3 & 3 & 3 & 3 & 3 & 3 & 3 & 3 & 3 & 3 & 3 & 3 & 3 & 2 \\
\hline \multirow{3}{*}{ Tekstur } & $20 \%$ & 3 & 3 & 3 & 3 & 3 & 3 & 3 & 3 & 3 & 3 & 3 & 3 & 3 & 3 & 3 & 3 & 2 \\
\hline & $35 \%$ & 4 & 4 & 4 & 4 & 4 & 4 & 4 & 4 & 4 & 4 & 4 & 4 & 4 & 4 & 4 & 4 & 3 \\
\hline & $50 \%$ & 4 & 4 & 4 & 4 & 4 & 4 & 4 & 4 & 4 & 4 & 4 & 4 & 4 & 4 & 4 & 4 & 3 \\
\hline
\end{tabular}

Keterangan :

Rasa

5 = Sangat manis

$4=$ Manis

3 = Cukup manis

$2=$ Sedikit manis

$1=$ Tidak manis
Aroma

$5=$ Sangat beraroma buah

$4=$ Beraroma buah

$3=$ Cukup beraroma buah

$2=$ Sedikit beraroma buah

$1=$ Tidak beraroma buah 
Warna

5 = Sangat berwarna cerah

4 = berwarna cerah

3 = Cukup berwarna cerah

$2=$ Sedikit berwarna cerah

1 = Tidak berwarna cerah
Tekstur

5 = Sangat kenyal

4 = Kenyal

3 = Cukup kenyal

$2=$ Kurang kenyal

1 = Sangat tidak kenyal

Setelah dilakukan pengamatan terhadap umur simpan produk sosis buah pisang, buah naga dan buah pepaya dengan menggunakan metode ESS (Extended Storage Study) dimana metode ESS adalah penentuan tanggal kadaluwarsa dengan cara menyimpan satu seri produk pada kondisi normal sehari-hari sambil dilakukan pengamatan terhadap penurunan mutunya (usable quality) hingga mencapai tingkat mutu kedaluwarsa (Andarwulan, 2012), maka langkah selanjutnya yaitu membuktikan ada atau tidaknya bakteri pada produk sosis buah. Berdasarkan hasil uji sampel sosis buah pada hari ke 16 menunjukkan terdapat bakteri pada sampel produk sosis buah yang dapat dilihat pada Gambar 2.
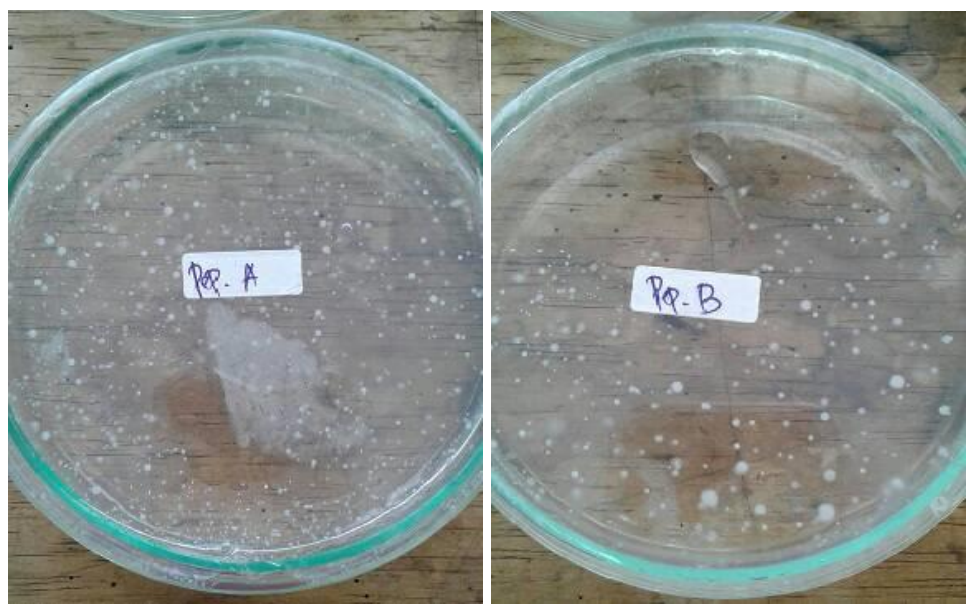

Gambar 2. Hasil uji mikroba

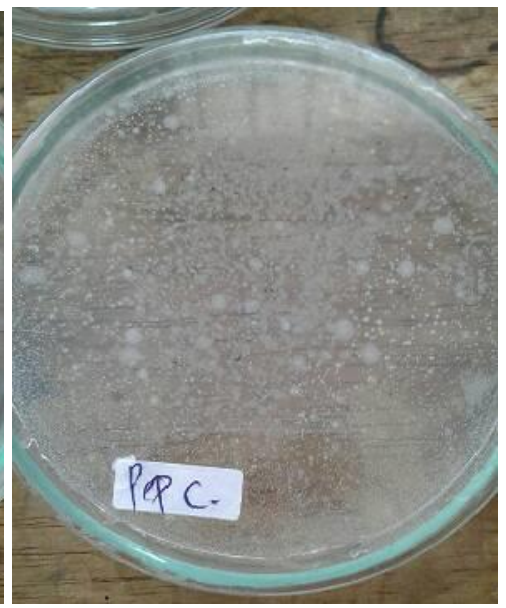

\section{(1) \\ 阷}

Keadaan fisik sosis buah setelah lebih dari 15 hari mengalami perubahan yang sangat mencolok hal ini dikarenakan adanya aktifitas mikroba dan meningkatnya kadar air pada produk sehingga menyebabkan produk sosis buah mengalami perubahan pada rasa, aroma, warna dan tekstur. Menurt Karlah (2014), peningkatanjumlah mikroorganisme yang tumbuh selama masa penyimpanan dapat diakibatkan karena adanya kenaikan kadar air pada produk. Kenaikan kadar air akan meningkatkan aktivitas air $\left(\mathrm{a}_{\mathrm{w}}\right)$ produk.

Perubahan tersebut juga dapat dibuktikan dengan melakukan uji bakteri terhadap produk osis buah dengan melakukan uji mikroba terhadap produk sosis buah yang telah mengalami perubahanfisik, setelah dilakukan uji mikroorganisme maka didapatkan hasil yaitu adanya bakteri gram positif. Bakteri gram positif adalah bakteri yang mempertahankan zat warna metil ungu sewaktu proses pewarnaan gram. Terdapat \pm 30 koloni pada tiap masing-masing cawan sampel produk sosis buah, dimana batas maksismum cemaran mikroba berdasarkan BPOM (2009) jenis makanan bassah olahan adalah ALT $\left(30^{\circ} \mathrm{C}\right.$ selama $\left.72 \mathrm{jam}\right) 1 \times 10^{4}$ koloni/gramatau $\mathrm{ml}$. 


\section{KESIMPULAN}

1. Formulasi terbaik dari masing-masing sosis buah yaitu produk sosis buah pisang, buah naga dan buah pepaya dengan perlakuan $\mathrm{C}(\mathrm{T} 50 \%=50 \mathrm{~g}$ tapioka: $50 \mathrm{~g}$ buah) dengan perolehan nilai rata-rata kesukaan tertinggi.

2. Produk sosis buah pisang, buah naga dan pepaya mampu bertahan selama 15 hari dengan penyimpanan produk di dalam freezer pada suhu $1^{\circ} \mathrm{C}$.

\section{DAFTAR PUSTAKA}

Andarwulan, N. dan P. Hariyadi. 2004. Perubahan mutu (fisik, kimia, mikrobiologi) produk pangan selama pengolahan dan penyimpanan produk pangan. Pelatihan Pendugaan Waktu Kedaluwarsa (Self Life), Bogor. 2004. Pusat Studi Pangan dan Gizi, Institut Pertanian Bogor.

Anwar A, dan Putri M.P (2012). Pengaruh Penggunaan Tepung Terigu Terhadap Sifat Sensoris Nugget Ikan Haruan. Tugas Akhir Diploma III. Program Studi Teknologi Industri Pertanian. Politeknik Tanah Laut.

BPOM. 2009. Pengujian Mikrobiologi Pangan. Jakarta: Pusat Pengujian Obat Dan Makanan Badan Pengawasan Obat Dan Makanan Republik Indonesia.

Karlah L. R., Mansauda, Fatimawali, Kojong, N. 2014. Analisis Cemaran Bakteri Coliform Pada Saus Tomat Jajanan Bakso Tusuk Yang Beredar Di Manado. Manado.

Khotimah, K dan Hartati, E.S (2013). Kualitas Fisika Kimia Sosis Ayam dengan Penggunaan Labu Merah (Cucurbita Moschata) sebagai Alternatif Pengganti Pewarna dan Antioksidan. Jurnal Ilmu Ternak, Juni 2013, Vol. 13, No.1

Prastini, A.I dan Widjanarko, S.B (2015). Pembuatan Sosis Ayam Menggunakan Gel Porang (Amorphophallus mueleri Blume) Sebagai Bahan Pengikat Terhadap Karakteristik Sosis. Jurnal Pangan dan Agroindustri Vol. 3 No 4.

Winarno, FG, 2002. Pangan, Gizi, Teknologi dan Konsumen. Jakarta: PT. Gramedia Pustaka Utama.

Witanto, B dkk (2013). Pembuatan Sosis Jamur Tiram Putih (pleurotus ostreatusjacq) dan Tepung Rebung Dengan Kombinasi Tepung Tapioka dan Karaginan (eucheuma cottoniidoty). Fakultas Teknobiologi Universitas Atma Jaya Yogyakarta, Jalan Babarsari No. 44, Sleman. 